\section{Transversus Abdominis Plane (TAP) Block for Postoperative Analgesia After Laparoscopic Cholecystectomy, A Retrospective Study}

\author{
Laparoskopik Kolesistektomi Sonrası \\ Postoperatif Ağrıda Transversus Abdominis Alan \\ Bloğu, Retrospektif Bir Çalışma
}

Ferda Yaman (1)

Gökhan Karaca (1)

Selim Colak (D)

Gökay Ates (1)

Faruk Pehlivanlı (1)

Isın Gencay (1)

Gülcin Aydın (D

\begin{abstract}
Objective: Laparoscopic cholecystectomy is a minimally invasive surgical procedure but it is still associated with postoperative pain within the first 24 hours. Ultrasound-guided transversus abdominis plane block is a regional anesthetic technique which provides postoperative analgesia in abdominal surgery. We aimed to determine the effects of the TAP block on discharge time, non-opioid and opioid consumption, shoulder tip pain, incidence of postoperative nausea and vomiting, and severity of pain evaluated with visual analogue scale in patients who underwent laparoscopic cholecystectomy.

Methods: Seventy-two eligible patients who underwent laparoscopic cholecystectomy were included in the study. In 38 patients ultrasound-guided TAP block was performed, and 34 patients were treated with conventional methods such as non-steroid anti-inflamatory drugs. Data related to VAS pain scores, shoulder tip pain, intraoperative opioid consumption, postoperative nonopioid and opioid consumption, nausea vomiting and discharge time were collected retrospectively to determine statistically significant differences between TAP block and non-TAP block groups.

Results: VAS pain scores were globally reduced at all time periods in two groups (significant group main effect, $F(7.760)=94.47, P<0.001)$. VAS pain scores were significantly lower at all measurement intervals except $24 \mathrm{~h}$ in the TAP group than in the non-TAP group. Shoulder pain was significantly higher in TAP block group than non-TAP block group $(p<0.001)$. Any statistically significant difference was not found between the groups in terms of intraoperative, and postoperative opioid consumption, discharge time, nausea and vomiting.

Conclusion: Ultrasound-guided TAP block is an effective regional analgesic technique to decrease postoperative abdominal pain, however TAP block does not reduce shoulder tip pain. Multimodal pain management is required after laparoscopic cholecystectomy.
\end{abstract}

Keywords: Postoperative pain, laparoscopic cholecystectomy, regional anesthesia, TAP block

öz

Amaç: Laparoskopik kolesistektomi, minimal invazif cerrahi girişim olmasına rağmen, postoperatif ilk 24 saat ağrı görülmektedir. Ultrasonografi eşliğinde transversus abdominis alan (TAP) bloğu, abdominal cerrahide postoperatif analjezi sağlayan rejyonal anestezi tekniğidir. Laparoskopik kolesistektomi nedeniyle opere edilen hastalarda, transversus abdominis alan bloğunun; taburculuk süresi, opioid ve opioid olmayan ilaçların tüketimi, bulantı, kusma, omuz ağrısı, vizüel analog ağrı skalasına (VAS) göre ağrı şiddetine etkilerini belirlemeyi amaçladık. Yöntem: Laparoskopik kolesistektomi olan 72 hasta çalışmaya dahil edildi. Otuz sekiz hastaya ultrasonografi eşliğinde TAP blok uygulanmış olup, 34 hastaya non steroid anti inflamatuvar ilaçlarla ağrı kontrolü sağlanmıştır. VAS skoru, omuz ağrısı, intraoperatif ve postoperatif opioid ve opioid olmayan ilaçların tüketimi, bulantı, kusma ve taburculuk süresi, TAP blok uygulanan ve uygulanmayan olmak üzere gruplar arası farklılıklar istatistiksel analiz ile araştırıldı.

Bulgular: VAS skorları her 2 grupta da genel olarak tüm zaman periyodlarında azalmıstır (anlamI temel etki, $F(7.760)=94.47, p<0.001)$. VAS ağrı skorları, TAP blok uygulanan grupta 24. saat hariç olmak üzere TAP uygulanmayan gruba göre anlamlı düşüktü. Omuz ağrısı, TAP blok uygulanan grupta anlamlı yüksek bulundu $(p<0.001)$. Intraoperatif ve postoperatif opioid tüketimi, bulantı, kusma, taburculuk süresi kıyaslandığında anlamlı fark bulunmadı.

Sonuç: Ultrasonografi eşliğinde TAP blok, abdominal ağrıya bağlı postoperatif ağrının azaltılmasında etkili bir rejyonal anestezi tekniğidir, ancak omuz ağrısını azaltmamaktadır. Laparoskopik kolesistektomi sonrası multimodal ağrı yönetimi gerekmektedir.

Anahtar kelimeler: Postoperatif ağrı, laparoskopik kolesistektomi, rejyonal anestezi, TAP blok
Alındığı tarih: 17.06 .2019 Kabul tarihi: 29.08.2019 Yayın tarihi: 31.10 .2019

Atıf vermek için: Yaman F, Karaca G, Colak S, Ates G, Pehlivanlı F, Gencay I, Aydın G. Transversus abdominis plane (TAP) block for postoperative analgesia after laparoscopic cholecystectomy, a retrospective study. JARSS 2019;27(4):285-90.

Ferda Yaman

Eskişehir Osmangazi Üniversitesi Tıp Fakültesi Anesteziyoloji ve Yoğun Bakım Anabilim Dalı,

Eskişehir - Türkiye $\checkmark$ fyaman@ogu.edu.tr ORCiD: 0000-0001-6847-1720

G. Karaca 0000-0002-5107-5999

F. Pehlivanlı 0000-0002-2175-8756 Kırıkkale Üniversitesi Tıp Fakültesi Genel Cerrahi Anabilim Dalı, Kırıkkale, Türkiye

S. Çolak 0000-0002-8364-982X I. Gençay 0000-0001-5279-9975

G. Aydın 0000-0001-9672-7666 Kırıkkale Üniversitesi Tıp Fakültesi Anesteziyoloji ve Yoğun Bakım Anabilim Dalı, Kırıkkale, Türkiye

G. Ateş 0000-0002-3718-2827 Akçaabat Haçkalı Devlet Hastanesi, Anesteziyoloji ve Yoğun Bakım Bölümü, Trabzon, Türkiye 


\section{INTRODUCTION}

Laparoscopic cholecystectomy is a common procedure in day-case surgery. Postoperative abdominal pain, shoulder tip pain, nausea, vomiting are the factors that effect and prolong the recovery time. Postoperative pain is at its peak on the day of surgery and the following day ${ }^{(1)}$. It is crucial to provide effective analgesia postoperatively. Adequate postoperative pain control provides early mobilization to reduce the complications such as deep vein thrombosis, pulmonary embolism, atelectasis, constipation and enhance the recovery, shorten the discharge time ${ }^{(2)}$. Treatments for relief of pain reportedly include conventional methods and regional anesthetic techniques ${ }^{(3)}$. Recently, multimodal analgesia approaches have been suggested so as to manage the postoperative pain ${ }^{(2)}$.

Transversus abdominis plane block (TAP) is a regional anesthetic technique that involves infiltration of local anesthetic agent into neuro-fascial plane between the internal oblique and transvers abdominis muscles to block the nerves originating from $\mathrm{T} 6$ to $\mathrm{L} 1$ which innervate the anterior abdominal wall layers from skin to the parietal peritoneum. TAP block was first described in 2002 by Rafi and performed percutaneously through the triangle of Petit with fascial clicks representing the passage of needle ${ }^{(4)}$. Recently, TAP block has been performed under ultrasound guidance. The use of ultrasound guidance improves the accurracy of infiltrating local anesthetic into the correct plane by direct visualisation and facilitates more frequent applications of regional analgesia techniques such as TAP block in different surgical procedures ${ }^{(5)}$. Several studies have suggested that transversus abdominis plane block reduces postoperative pain intensity and requirement for opioid. It also prolongs the time interval to the first analgesic request however there are many controversies about its superiority over other analgesic modalities ${ }^{(6)}$.

This study was designed to determine the effects of TAP block on time to discharge, opioid consumption, shoulder tip pain, incidence of postoperative nausea and vomiting, severity of pain evaluated based on visual analogue scale in patients who underwent laparoscopic cholecystectomy.

\section{MATERIAL and METHODS}

After approval for the study (decision number 10.06. 2015/21-02) was obtained from the ethics committee, database to identify patients operated for laparoscopic cholecystectomy reversal between October 6, 2015 and October 6, 2014 were evaluated. Patients who underwent an intervention in addition to cholecystectomy such as hernia repair or laparotomy, and patients under age of 18 years were excluded from the study. Seventy-two patients with ASA (American Society of Anesthesiologists) I-II were eligible for the study, and in 38 of these patients, ultrasound-guided transversus abdominis plane block was performed by either a staff anesthesiologist or anesthesiology resident when the patients were under general anesthesia and 34 patients were treated with conventional methods using nonsteroidal antiinflamatory drugs. Third year residents performed TAP blocks under supervision of a staff anesthesiologist. Standard monitorization procedures; noninvasive blood pressure measurements, electrocardiography, pulse oximetry, capnometry were applied. All patients received standardized general anesthetic technique with 2-2.5 $\mathrm{mg} \mathrm{kg}^{-1}$ propofol, 0.6 $\mathrm{mg} \mathrm{kg}^{-1}$ rocuronium, 1-2 $\mathrm{mcg} \mathrm{kg}^{-1}$ fentanyl and anesthesia was maintained with sevoflurane and oxygenair mixture. Intraoperatively various doses of additional opiods were used, and recorded in anesthesia follow-up form. Before surgery, ultrasound-guided TAP block was performed in supine position under general anesthesia (Esaote MyLab five, Italy). The ultrasound probe (linear 5-12 Hz) was placed transversely on the flank between iliac crest and costal margin. The ultrasound image that clearly identified the external oblique, internal oblique and transversus abdominis muscles was determined. A 22 gauge, $50 \mathrm{~mm}$ needle (Stimuplex, B. Braun, Melsungen, Germany) was used by in-plane technique, and 20 $\mathrm{mL} \% 0.25$ bupivacaine was injected between internal oblique and transversus abdominis muscles. TAP block was performed bilaterally. Laparoscopic cholecystectomy was a standard procedure performed using four trocars by general surgeons. Supraumbilical incision was performed to insert $12-\mathrm{mm}$ and 11-mm trocars into epigastrium to the left of midline. Then $5-\mathrm{mm}$ trocars were inserted into the right upper abdomen cavity under direct vision. 
Patients were operated under standard pressure of pneumoperitoneum (12-13 $\mathrm{mmHg}$ ).

After surgery, visiual analogue scale (VAS, $0=$ no pain, $10=$ the severest pain imaginable) was used to assess the pain intensity at $0,2,4,6,8,10,12,24$ hours. Patients were requested to rate the intensity of pain at 0 hour using VAS scoring system in the recovery room before they were transferred to the ward. Patients with a VAS score greater than 4 were treated with $50 \mathrm{mg}$ dexketoprofen trometamol given every 6 hours, $1 \mathrm{mg} \mathrm{kg}^{-1}$ tramadol was administered to patients whose pain was not relieved with dexketoprofen trometamol.

Demographic data of the patients such as age, gender, height, weight, body mass index, ASA physical status were recorded. Also nausea, vomiting and shoulder pain, intraoperative opioid consumption, postoperative opioid consumption, discharge time from hospital were recorded. Postoperative opioid consumption (if used) was recorded without calculating dose of opioid.

For statistical analyses, SPSS (Statistical Package for the Social Sciences) version 21 (SPSS Inc., Chicago, Illinois, United States) was used. Demographic data such as age, weight, height and discharge time, intraoperative opioid consumption, shoulder pain were analyzed with Student's t-test. VAS score was measured repetitively at 8 different time points within the first 24 hours. VAS scores and group were involved in repeated measures of Anova as dependent and independent variables, respectively. Continuous data were presented as mean \pm standard deviations (SD) for normally distributed variables. A $p<0.05$ was considered to be statistically significant.

\section{RESULTS}

Seventy-two eligible patients operated for laparoscopic cholecystectomy reversal between october 6 , 2015 and october 6, 2014 were enrolled the study. Thirty-eight (8 male, 30 female) patients received ultrasound-guided TAP block preoperatively, while thirty-two ( 7 male, 25 female) cases did not. ASA grade was between ASA I-II. No significant difference was found between the groups in terms of ASA gra- des. Data in two groups (TAP block vs non-TAP block) regarding age, sex, weight, height and body mass index, intraoperative opioid consumption $\left(\mu \mathrm{g} \mathrm{kg}^{-1}\right)$, time to discharge (in hours) are depicted in Table I; without any significant intergroup differences. VAS pain scores were globally reduced at all time points in two groups (significant group main effect, $F(7.760)=94.47, P<0.001)$. VAS pain scores were significantly lower at all measurement time points except 24th $\mathrm{hr}$ in the TAP group than in the non-TAP group. Results shown in Table II indicate that VAS

Table I. Demografic profile of patients and results of intraoperatively opioid consumption, discharge time, shoulder pain

\begin{tabular}{|c|c|c|c|c|c|}
\hline & Groups & $\mathbf{N}$ & Mean & $\begin{array}{c}\text { Std. } \\
\text { Deviation }\end{array}$ & p \\
\hline $\mathrm{BMI}\left(\mathrm{kg} \mathrm{m}^{-2}\right)$ & $\begin{array}{l}\text { TAP } \\
\text { CONTROL }\end{array}$ & $\begin{array}{l}38 \\
34\end{array}$ & $\begin{array}{l}28.0671 \\
28.3634\end{array}$ & $\begin{array}{l}4.63252 \\
3.70653\end{array}$ & 0.767 \\
\hline Age (years) & $\begin{array}{l}\text { TAP } \\
\text { CONTROL }\end{array}$ & $\begin{array}{l}38 \\
34\end{array}$ & $\begin{array}{l}44.16 \\
46.35\end{array}$ & $\begin{array}{c}13.70 \\
15\end{array}$ & 0.954 \\
\hline $\begin{array}{l}\text { Intraoperatively } \\
\text { opioid consumption } \\
\text { (fentanyl, } \mu \mathrm{kg}^{-1} \text { ) }\end{array}$ & $\begin{array}{l}\text { TAP } \\
\text { CONTROL }\end{array}$ & $\begin{array}{l}38 \\
34\end{array}$ & $\begin{array}{l}1.347 \\
1.529\end{array}$ & $\begin{array}{l}0.4298 \\
0.5066\end{array}$ & 0.107 \\
\hline Discharge time (hours) & $\begin{array}{l}\text { TAP } \\
\text { CONTROL }\end{array}$ & $\begin{array}{l}38 \\
34\end{array}$ & $\begin{array}{l}35.26 \\
35.38\end{array}$ & $\begin{array}{l}1.87 \\
1.28\end{array}$ & 0.756 \\
\hline
\end{tabular}

Table II. Abdominal pain scores between the groups

\begin{tabular}{llcccc}
\hline Groups & $\begin{array}{l}\text { Time } \\
\text { (hour) }\end{array}$ & Mean & $\begin{array}{c}\text { Std. } \\
\text { Error }\end{array}$ & $\begin{array}{c}\text { 95\% Lower } \\
\text { Bound }\end{array}$ & $\begin{array}{c}\text { 95\% Upper } \\
\text { Bound }\end{array}$ \\
\hline CONTROL & $0^{\text {th }}$ & 6.882 & 0.17 & 6.543 & 7.222 \\
& $2^{\text {th }}$ & 5.618 & 0.149 & 5.321 & 5.915 \\
& $4^{\text {th }}$ & 5.235 & 0.142 & 4.952 & 5.518 \\
& $6^{\text {th }}$ & 4.647 & 0.142 & 4.363 & 4.931 \\
& $8^{\text {th }}$ & 4.088 & 0.131 & 3.828 & 4.349 \\
& $10^{\text {th }}$ & 3.647 & 0.104 & 3.439 & 3.855 \\
& $12^{\text {th }}$ & 2.824 & 0.095 & 2.633 & 3.014 \\
TAP & $24^{\text {th }}$ & 2.059 & 0.1 & 1.86 & 2.258 \\
& $0^{\text {th }}$ & 4.737 & 0.161 & 4.416 & 5.058 \\
& $2^{\text {th }}$ & 4.079 & 0.141 & 3.798 & 4.36 \\
& $4^{\text {th }}$ & 3.711 & 0.134 & 3.443 & 3.978 \\
& $6^{\text {th }}$ & 3.342 & 0.135 & 3.073 & 3.611 \\
& $8^{\text {th }}$ & 2.947 & 0.124 & 2.701 & 3.194 \\
& $10^{\text {th }}$ & 2.684 & 0.099 & 2.487 & 2.881 \\
& $12^{\text {th }}$ & 2.079 & 0.09 & 1.899 & 2.259 \\
& $24^{\text {th }}$ & 1.711 & 0.094 & 1.522 & 1.899 \\
& & & & & \\
\hline
\end{tabular}

Table III. Shoulder pain between the groups

\begin{tabular}{lcc}
\hline Shoulder pain & TAP & Control \\
\hline Absent & 13 & 31 \\
Present & 25 & 3 \\
\hline \multicolumn{3}{c}{ chi-square $=24.5$ and $p<0.001$} \\
\hline
\end{tabular}


pain scores in non-TAP group were significantly lower than TAP group at 0, 2, 4, 6, 8, 10, 12 hours (significant time period effect, $F(7.64)=143.43$, $\mathrm{P}<0.001)$, however VAS scores at $24^{\text {th }}$ hour were not statistically different (significant group $\mathrm{x}$ time interaction, $f(7.64)=6.69, p<0.001$ ) between groups. Collected data for postoperative shoulder pain, nausea, vomiting, postoperative opioid consumption were recorded as absent or present. Shoulder pain was significantly more severe in TAP group than nonTAP group $(p<0.001)$ (Table III). Patients complained of shoulder tip pain especially at postoperative first 6 hours. Any statistically significant difference was not found regarding intraoperative opioid consumption and incidence of nausea, and vomiting. Finally, our analysis regarding postoperative, and intraoperative opioid consumption, discharge time did not reveal any statistically significant difference between the groups. Any complications were not encountered.

\section{DISCUSSION}

Laparoscopic cholecystectomy is a widely performed surgery that does require large incisions, with resultant less pain and faster recovery ${ }^{(7)}$. However, patients undergoing laparoscopic cholecystectomy have abdominal and shoulder tip pain leading to patient's discomfort ${ }^{(8)}$. Inadequate pain control delays the recovery and prolongs the time to discharge so the advantage factor of laparoscopic procedure may be lost especially in planned day-case surgery (9). Postoperative abdominal and shoulder tip pain, nausea and vomiting due to peritoneal stretching and diaphragmatic irritation are induced by pneumoperitoneum and residual $\mathrm{CO}_{2}{ }^{\left({ }^{8}\right)}$. Ultrasound-guided TAP block has been performed for pain relief in patients undergoing laparoscopic cholecystectomy with controversial results ${ }^{(10-13)}$. El-Dawletly et al. ${ }^{(11)}$ evaluated intraoperative and postoperative opioid consumption without evaluating pain scores between TAP and non- TAP block groups and showed that TAP block reduces the perioperative opioid consumption. In this study, all patients in two groups required additional intraoperative fentanyl administration dependent on increase in baseline measurements of heart rate and noninvasive arterial blood pressure so intraoperative opioid consumption between the groups was not statistically significant. Nonetheless, postoperative opioid consumption was statistically significantly reduced in the TAP group $(p<0.05)$. Peterson et al. ${ }^{(10)}$ compared TAP block with placebo and showed significantly lower pain scores within the first 8 hours in the TAP block group. Also, opioid consumption was lower within the first postoperative 2 hours in TAP group. However, Oritz et al. ${ }^{(13)}$ found no significant difference in pain scores in the first 24 hours when they compared TAP block and local anesthetic infiltration of trocar insertion sites. In this study, VAS scores for abdominal pain were significantly lower in TAP group than non-TAP block group at first 12 hours, however at $24^{\text {th }}$ hour no significant difference was found. However, it should be noted that nonopioid analgesic was administered in TAP block group for shoulder tip pain relief. Multimodal analgesia was performed in TAP group with systemic antiinflammatory drug. In our analgesic regimen, dexketoprofen trometamol $50 \mathrm{mg}$ was administered to patients in TAP group. Limitation of this study was that shoulder tip pain could not be evaluated based on VAS scores, collected data about shoulder tip pain necessitated the administration of dexketoprofen trometamol by nursing stuff. It should be pointed out that lower abdominal pain scores without opioid consumption were obtained within postoperative 24 hours in TAP group with systemic antiinflamatory drugs. Patients suffered from shoulder pain in the TAP group. These results suggested that multimodal pain control is more effective in patients undergoing laparoscopic cholecystectomy performed with TAP block.

In this study, besides abdominal pain, shoulder tip pain was emphasized by patients and results of the study have shown that shoulder tip pain was significantly more severe in TAP group than non-TAP group $(p<0.001)$, however VAS scores for abdominal pain were comparatively lower. Postoperative pain relief in non-TAP group provided with systemic analgesic drugs may indicate that shoulder tip pain was significantly more severe in TAP group than non-TAP group. TAP block provides analgesia of anterior abdominal wall between the levels T7-L1 dermatomes ${ }^{(4)}$. Mechanism of pain occurring after laparoscopic procedures is complex and multifactorial, penetration of abdominal wall with trocar produces soma- 
tic component of pain ${ }^{(14)}$. Pneumoperitoneum produced by $\mathrm{CO}_{2}$ insufflation causes traction of nerves resulting in irritation of phrenic nerve which may be projected to the shoulder via C4 pathway ${ }^{(15)}$. The residual volume of pneumoperitoneum is the major factor that causes the shoulder pain after laparoscopic surgery. Khanna et al. ${ }^{(15)}$ showed that pulmonary recruitment manoeuvre in Trendelenburg position at the end of the procedure significantly reduces postoperative pain. Elamin et al. (2) analyzed that $45 \%$ of patients reported shoulder tip pain in both TAP block group and non-TAP block group. It has been suggested that TAP block and infiltration of local anesthetic at trocar insertion sites does not have any effect on shoulder tip pain. In clinical practice, any procedure such as deflation in Trendelenburg position was not performed, but after procedure opening of all port sites for efflux of residual $\mathrm{CO}_{2}$ was performed routinely.

In this study, based on the results regarding intraoperative, and postoperative opioid consumption, time to discharge, nausea and vomiting, any statistically significant difference was not found between the groups. The disadvantage of this retrospective study was the lack of data on the amount of opioid used to determine postoperative opioid consumption. Patients whose pain was not relieved with dexketoprofen trometamol received tramadol at a dose of $1 \mathrm{mg} \mathrm{kg}^{-1}$.

Results of a recent study analyzing the role of pneumoperitoneum on the incidence of shoulder tip pain revealed that the incidence of shoulder pain was 2.8 times lower in low-pressure pneumoperitoneum when compared with standard pressure pneumoperitoneum ${ }^{(16)}$. In this study, standard pressure at 12 $\mathrm{mmHg}$ was prefered by general surgeons and opioid and non-opioid analgesic regimens were required to treat the shoulder tip pain. This study has demonstrated that solely TAP block is not enough to manage the visceral pain. Another recent study did not find any advantage of ultrasound-guided TAP blocks over wound infiltration with local anesthetic in elective laparoscopic colonic surgery ${ }^{(17)}$. TAP block with systemic antiinflammatory drug is more effective in providing postoperative pain relief.

\section{CONCLUSIONS}

Ultrasound-guided TAP block is an effective regional analgesic technique to relieve abdominal pain according to postoperative pain scores however TAP block did not reduce shoulder tip pain. Results of this study suggest that multimodal pain control is required to provide effective postoperative analgesia for early discharge of patients then laparoscopic cholecystectomy may become a day-case surgery.

Etik Kurul Onayı: Kırıkkale Üniversitesi Klinik Araştırmalar Etik Kurul onayı alınmıştır (06.10.2015-21/02).

Çıkar Çatışması: Yoktur

Finansal Destek: Yoktur

Hasta Onamı: Hastaların onamları alındı.

Ethics Committee Approval: Kirikkale University Clinical Research Ethics Committee approval was received (06.10.2015-21 / 02).

Conflict of Interest: None

Funding: None

Informed Consent: The patients' consent were obtained.

\section{REFERENCES}

1. Singla S, Mittal G, Raghav RK. Pain management after laparoscopic cholecystectomy-a randomized prospective trial of low pressure and standard pressure pneumoperitoneum. Journal of Clinical and Diagnostic Research: JCDR. 2014;8:92. https://doi.org/10.7860/JCDR/2014/7782.4017

2. Elamin G, Waters PS, Hamid H, et al. Efficacy of a laparoscopically delivered transversus abdominis plane block technique during elective laparoscopic cholecystectomy: a prospective, double-blind randomized trial. Journal of the American College of Surgeons. 2015;221:335-44. https://doi.org/10.1016/j.jamcollsurg.2015.03.030

3. Johns N, O'neill S, Ventham NT, Barron F, Brady RR, Daniel T. Clinical effectiveness of transversus abdominis plane (TAP) block in abdominal surgery: a systematic review and meta-analysis. Colorectal Disease. 2012;14:e635-42. https://doi.org/10.1111/j.1463-1318.2012.03104.x

4. Rafi AN. Abdominal field block: a new approach via the lumbar triangle. Anaesthesia. 2001;56:1024-6. https://doi.org/10.1046/j.1365-2044.2001.02279-40.x

5. Kadam VR. Ultrasound-guided quadratus lumborum block as a postoperative analgesic technique for laparotomy. Journal of anaesthesiology. Clinical Pharmacology. 2013;29:550. https://doi.org/10.4103/0970-9185.119148

6. Saliminia A, Azimaraghi O, Babayipour S, Ardavan K, 
Movafegh A. Efficacy of transverse abdominis plane block in reduction of postoperation pain in laparoscopic cholecystectomy. Acta Anaesthesiologica Taiwanica. 2015;53:119-22.

https://doi.org/10.1016/j.aat.2015.07.003

7. Milas M, Deveđija S, Trkulja V. Single incision versus standard multiport laparoscopic cholecystectomy: up-dated systematic review and meta-analysis of randomized trials. the Surgeon. 2014;12:271-89. https://doi.org/10.1016/j.surge.2014.01.009

8. Sarvestani AS, Zamiri M. Residual pneumoperitoneum volume and postlaparoscopic cholecystectomy pain. Anesthesiology and Pain Medicine. 2014;4:e17366. https://doi.org/10.5812/aapm.17366

9. Reddy VS, Brown JD, Ku B, Gilchrist BF, Farkas DT. Effect of pain medication choice on emergency room visits for pain after ambulatory laparoscopic cholecystectomy. The American Surgeon. 2015;81:826-8.

10. Petersen PL, Stjernholm P, Kristiansen VB et al. The beneficial effect of transversus abdominis plane block after laparoscopic cholecystectomy in day-case surgery: a randomized clinical trial. Anesthesia \& Analgesia. 2012;115:527-33. https://doi.org/10.1213/ANE.0b013e318261f16e

11. El-Dawlatly AA, Turkistani A, Kettner SC, et al. Ultrasound-guided transversus abdominis plane block: description of a new technique and comparison with conventional systemic analgesia during laparoscopic cholecystectomy. British Journal of Anaesthesia. 2009;102:763-7. https://doi.org/10.1093/bja/aep067

12. Ra YS, Kim CH, Lee GY, Han JI. The analgesic effect of the ultrasound-guided transverse abdominis plane block after laparoscopic cholecystectomy. Korean
Journal of Anesthesiology. 2010;58:362-8.

https://doi.org/10.4097/kjae.2010.58.4.362

13. Ortiz J, Suliburk JW, Wu K, et al. Bilateral transversus abdominis plane block does not decrease postoperative pain after laparoscopic cholecystectomy when compared with local anesthetic infiltration of trocar insertion sites. Regional anesthesia and pain medicine. 2012;37:188-92.

https://doi.org/10.1097/AAP.0b013e318244851b

14. McCloy $R$, Randall $D$, Schug $S A$, et al. Is smaller necessarily better? A systematic review comparing the effects of minilaparoscopic and conventional laparoscopic cholecystectomy on patient outcomes. Surgical Endoscopy. 2008;22:2541-53. https://doi.org/10.1007/s00464-008-0055-1

15. Khanna A, Sezen E, Barlow A, Rayt H, Finch JG. Randomized clinical trial of a simple pulmonary recruitment manoeuvre to reduce pain after laparoscopy. British Journal of Surgery. 2013;100:1290-4. https://doi.org/10.1002/bjs.9202

16. Yasir M, Mehta KS, Banday VH, Aiman A, Masood I, Iqbal B. Evaluation of post operative shoulder tip pain in low pressure versus standard pressure pneumoperitoneum during laparoscopic cholecystectomy. the Surgeon. 2012;10:71-4. https://doi.org/10.1016/j.surge.2011.02.003

17. Rashid A, Gorissen KJ, Ris F, et al. No benefit of ultrasound-guided transversus abdominis plane blocks over wound infiltration with local anaesthetic in elective laparoscopic colonic surgery: results of a double-blind randomized controlled trial. Colorectal Disease. 2017;19:681-9. https://doi.org/10.1111/codi.13578 